\title{
Appraisal of Child Care Arrangements in Ekiti State Nigeria: Parents' Perceptual Analysis
}

\author{
Taiwo Frances Gbadegesin \\ Olusola Isola Alabi
}

Institute of Education, Ekiti State University, Ado - Ekiti, Nigeria

Olusolaalabi170@yahoo.com, taiwogbadegesin@yahoo.com

\author{
Doi:10.5901/jesr.2014.v4n3p99
}

\begin{abstract}
Purpose: This study identifies different kinds and combinations of child care arrangements and empirically examines parents' perception on various child care arrangements in Ekiti State. It also determines if there is any relationship between the parents' demographic variables and their perception on different kinds of child care arrangements. Methodology: Structured questionnaire tagged "Assessment of Parental Child Care Arrangement (APCA)" was administered on a sample of working parents within these categories: Parent-Teacher Association (PTA) Members of preschool children, Community Primary Health Care Centres workers and parents working in public and private institutions in Ado Ekiti, the capital city of Ekiti State, Nigeria. Data collected were analyzed using descriptive statistics, correlation and chi-square. Findings: It was found that crèche/day care centres and nanny/baby sitters are the most practised childcare arrangements. While the majority of the sampled parents have a high positive impression on the use of crèche/daycare centres, they also have a high negative impression on nanny/baby sitters. It was further found that the parents' demographic variables have different levels of significance with the parents' perceptions. Practical Implication: It will help stakeholders in early childhood education to know the perceptions of working parents on the use of different kinds of child care arrangements in such an environment. The significance of the study to major stakeholders in the field of early childhood education is further reinforced with how the study has carried along the parents' decision making on the use of child care arrangement that will cater for their children total needs. Originality: The findings from this study are assumed to help parents make informed decision about an appropriate child care arrangement relevant to the ideology of universal basic education (UBE). The relationship between parents' demographics and the childcare arrangement adopted provides a good ground for policy makers on early childhood development programme.
\end{abstract}

Keywords: Child Care Arrangement, Parent, Early Childhood Education,

\section{Introduction}

Ekiti State of Nigeria has embraced the UBE programme in its entirety. The state with the slogan "fountain of knowledge" is believed to have produced the most educated individuals in the country as they place high premium on education and work. Having a job to do is a cultural norm with the belief that "hard work is the antidote of poverty" most of their citizenry are engaged in the civil service, private establishment, artisans, corporate organizations and self employed. It is thus perceived that while parents are away at work, majority of preschool children in Ado Ekiti regardless of age or income of parents are regularly cared for by individuals other than their parents.

Recent studies suggest that non-parental child care is common in early childhood due to the increasing number of dual-earner and one-parent families (Anderson \& Levine, 1999; Huston, Chang \& Gennetian, 2002; Baxter, 2005; Hand, 2005). Different child care arrangements are adopted nowadays in caring for children while their parents are busy trying to make ends meet. It has been established that access to affordable, good quality child care is frequently acknowledged to be an essential tool in achieving high workforce participation, maintaining work/family balance and providing good developmental outcomes for children. As a result, child care centres, family child care homes, relatives, grandparents and nannies/house-help maids have become essential child care arrangement options available to working parents during their children formative years. According to Meyer (2006), children represent the workforce of the future and their healthy early development is affected by the quality of care that they receive. It is thus imperative to understand the kind of non-parental child care arrangement that working parents choose for their children and their perception on the different options available to them because of the role it plays in helping working parents to concentrate on their job and the impact it has on the children later cognitive and social development. 
The important role of child care for both maternal employment and human capital development gives some urgency to questions about how parents arrange child care and the role of local, state and national policies in shaping their child care options (Meyers and Jordan, 2006). Parents especially mothers in the labour market often have to make various decisions when trying to balance their work and home life and such choices include; appropriate kind of care for their wards while they work, loosening of their employment commitment to reconcile their time allocation to child care so as to make a good mother, temptation to leave successful careers for full time child care in the home due to overlapping workplace pushes and family pulls and social pressure to succeed as both employees and mothers in the face of gender awareness realities.

\section{The Concept of Child Care}

Child care is an umbrella term referring to any form of non-parental care that occurs on a regular basis (Huston, Chang \& Gennetian, 2002). Child care has become an issue of public policy concern due to the influx of a large number of working mothers into the workforce. Children are cared for in various arrangements ranging from informal care giving by relatives and friends to formal care in family child care homes, pre-school settings. In fact, child care has become a fact for the majority of parents with young children.

Child care types are centre-based (day care centres, crèche, nursery school), family child care (care by a nonrelative in the provider's home), baby-sitters or nanny (care by a non relative in the child's home), relative care (care by a relative either in the child's home or provider's home) and grandparent care (care provided my grandparents of the child either in the child home or provider's home). A centre refers to a group settings designed for the care of young children. It includes programme designed primarily for the enrichment of early education as well as setting designed primarily to provide care while parents are working. This centre must be licensed and is subject to some regulations regarding physical safety, ratio of caregivers to pupils, methodology and curriculum to be followed. Relatives include siblings, uncles, cousins and aunts while nonrelatives include in-home babysitters and nannies, neighbours, family friends and housemaids. Grandparent care can take many forms, from occasional babysitting through regular help with childcare to being the sole provider of child care while parents work or living with grandchildren in an extended family setting.

\section{Influencing Factors and Problems of Child Care}

There is a wide spread agreement that child care decisions are complex. Child care is one component of a complex set of family management decisions that are often made with the highest carefulness. Choosing a child care arrangement that is suitable is one of the most important decisions working parents have to make because there is no similar control and benchmark for child care. Good quality childcare has been linked with better short and long term outcomes for children and for society as a whole (Anderson \& Levine, 1999; Anderson, Foster \& Frisvold, 2004).

The challenge of parents however is the difficulty in finding appropriate child care. The research community has amassed considerable evidence about factors and processes associated with child care decisions. Some evidence does suggest that mothers' decision to use or not use child care is based more on a desire to look after their children themselves, rather than on problems with accessing appropriate child care (see Baxter, 2005 cited in Hand, 2005). Many parents struggle to find a child care provider on short notice after getting a job or in a bit to respond to the demands of a new job, a change in work schedule and family changes. Some often make choices with limited information about the actual quality, convenience or even the cost of alternative child care. Thus, child care decision making process seems to be prone to changes as the situation demands.

Research has shown that parents consider the following set of factors in choosing a child care arrangement for their children; hours of operation, finances, convenience of the location, availability of transportation, the quality and quantity of different types of child care, the age and developmental goals for individual children in the family, conflicting needs for different family members, family beliefs, values and preferences including cultural beliefs and language use. Child care arrangement choice can also include the specific characteristics of the child care programme, the desire for a provider with shared values, religion and culture, the convenience of time and location or the reliability of the provider. Constraints can however include factors such as budget, employment schedule and availability of services in the surrounding environment (Casper \& Smith, 2004). Families with high socio-economic status often have more success in preparing their children for school because they have access to a wide range of resources to promote and support young children's development. They are also able to provide them with high quality child care. In addition, families with high socio-economic status often seek information to help them better prepare their young children for school. Higher income 
families are most likely to select in-home care, nonrelatives and child care centres at higher rates than families with low income who choose childcare homes, federally subsidized care centres and relatives more frequently (Capizzano \& Adams, 2004). Weisner (2004) also found that low-income families use more home-based than center-based programme for their wards. It may be assumed that if parents find any other alternatives over a particular type of child care arrangement they will opt for it, for example a low income earner parent may choose to take his or her child to relatives if pre-school fees is on the high side or there is no daycare centers in the neighbourhood.

Previous studies show that child's age is strongly tied to parental child care arrangement choices (Hofferth \& Wissoker, 1992,). Parents often make choices about their children child care arrangements based on the age of child. Parents of infants prefer home-based and relatives care while parents of pre-school children are more likely to choose center-based care. Pre-school children of different ages vary in their developmental needs and certain forms of child care are often more readily available for children according to their age group. However, it is necessary to place the interests of the child at the centre of decision making around early childhood education services. The quality of the physical, social and educational environments children experience in child care and the effect on their socio-emotional, intellectual and behavioural development is also very crucial and should be placed at the centre of any decision making of appropriate child care arrangement.

Parental employment and risk of child developmental problems are of concern to parent, school administrator and policymakers. Due to the increasing rate at which mothers participate in labour force, adequate child care has become quite important to many working parents. In Nigeria, although many assume that the best place for a young child to learn is at home with her mother or relatives, the reality is that parents are faced with a life stage in which they have to combine their professional and developmental goals with parenting and child care. Hence, parenting is often seen as a double bind in which parents are often seen as failure if they are unable to provide adequate care for their children while working. Non-parental care is common but also has some cost implications and the types of care vary in their advantages and disadvantages.

Crosby, Gennetian and Hudson (2005) found out that families supported by generous child care assistance programme tended to choose center care but if support was less comprehensive, families ended up in home-based care provided by relatives or nonrelatives. However, there may be cases where relative themselves are not available to provide child care, parents especially the unemployed ones may have to stay at home and cater for their children.

Thus, the aim of this research is to assess the different kinds and combinations of parental child care arrangements in Ekiti State, Nigeria. In addition, this study examines the parents' perceptions of the different child care arrangement options available for them. This study also determined if there is any significant relationship between the parents' demographic variables and their perception of each of the child care arrangement.

\section{Research Questions}

The following research questions were raised for the study:

1. What are the different kinds and combinations of child care arrangement that parents use in Ado Ekiti?

2. What are the parents' perceptions of the different kinds of child care arrangement in Ado Ekiti?

3. Is there any significant relationship between the parents' demographic variables and their perceptions of each type of child care arrangement?

\section{Research Hypothesis}

- $\quad H^{\circ}$ : There is no significant relationship between the parents' demographic variables and their perceptions of each type of child care arrangement

- $\quad \mathbf{H 1}$ : There is a significant relationship between the parents' demographic variables and their perceptions of each type of child care arrangement

\section{Research Methodology}

This research adopts a survey research design technique. The instrument for the study is a self- constructed questionnaire titled "Assessment of Parental Child Care Arrangement (APCA)" which was pilot tested on 20 parents outside the study area four weeks prior to the study. To achieve the purpose of this study, the questionnaires were administered directly and physically on a purposive sample of 200 parents within these categories: Parent-Teacher 
Association (PTA) Members of preschool children, parents at the Community Primary Health Care Centres workers and parents working in public and private institutions in Ado Ekiti, Ekiti State. Out of the 200 questionnaires administered, 150 $(75 \%)$ questionnaires were eventually retrieved and useful for the study. Table I presents the target population for the study and the response rate.

Table I: The Response Rate of Target Population

\begin{tabular}{|c|l|c|c|}
\hline S/N & \multicolumn{1}{|c|}{ Category of Target Population } & Target sample size & Response rate \\
\hline 1. & Parents of PTA members of preschools. & 50 & 42 \\
\hline 2. & Public/Civil servants at government ministries & 50 & 35 \\
\hline 3. & Parents at Private/Corporate organizations & 50 & 43 \\
\hline 4. & Parents at Primary HealthCare centres & 50 & 30 \\
\hline & Total & 200 & 150 \\
\hline
\end{tabular}

Implicit from the table above, 200 parents were purposively sampled, out of which 150 questionnaires were returned valid. Table II presents the Descriptive Summary of Socio-demographic variables of the respondents.

Table II: Descriptive Summary of Socio-Demographic Variables

\begin{tabular}{|c|c|c|c|}
\hline Variables & Levels & Frequency (f) & Percent (\%) \\
\hline \multirow[t]{4}{*}{ Sex } & Male & 43 & 28.7 \\
\hline & Female & 100 & 66.7 \\
\hline & No Response & 7 & 4.7 \\
\hline & Total & 150 & 100.0 \\
\hline \multirow[t]{5}{*}{ Marital Status } & Single mother & 7 & 4.7 \\
\hline & Married & 128 & 85.3 \\
\hline & Divorced & 3 & 2.0 \\
\hline & No Response & 12 & 8.0 \\
\hline & Total & 150 & 100.0 \\
\hline \multirow[t]{6}{*}{ No of Children } & One & 25 & 16.7 \\
\hline & Two-Three & 68 & 45.3 \\
\hline & Four- Six & 48 & 32.0 \\
\hline & Above 6 & 1 & .7 \\
\hline & No Response & 8 & 5.3 \\
\hline & Total & 150 & 100.0 \\
\hline \multirow[t]{4}{*}{ Type of Family } & Nuclear & 127 & 84.7 \\
\hline & Extended & 11 & 7.3 \\
\hline & No Response & 12 & 8.0 \\
\hline & Total & 150 & 100.0 \\
\hline \multirow[t]{7}{*}{ Age } & 25yrs and below & 12 & 8.0 \\
\hline & $26-30 y r s$ & 24 & 16.0 \\
\hline & 31-35yrs & 25 & 16.7 \\
\hline & 36-40yrs & 27 & 18.0 \\
\hline & 40yrs and above & 54 & 36.0 \\
\hline & \begin{tabular}{|l|} 
No Response \\
\end{tabular} & 8 & 5.3 \\
\hline & Total & 150 & 100.0 \\
\hline Employment Status & Public/Civil Servant & 99 & 66.0 \\
\hline
\end{tabular}




\begin{tabular}{|c|c|c|c|}
\hline Variables & Levels & Frequency (f) & Percent (\%) \\
\hline \multirow[t]{10}{*}{ Sex } & Male & 43 & 28.7 \\
\hline & Female & 100 & 66.7 \\
\hline & No Response & 7 & 4.7 \\
\hline & Private Establishment & 17 & 11.3 \\
\hline & Corporate Organization & 11 & 7.3 \\
\hline & Artisans & 1 & .7 \\
\hline & Self Employed & 17 & 11.3 \\
\hline & Retiree & 1 & .7 \\
\hline & No Response & 4 & 2.7 \\
\hline & Total & 150 & 100.0 \\
\hline \multirow[t]{8}{*}{ Educational Qualification } & Primary School Cert. & 1 & .7 \\
\hline & SSCE & 5 & 3.3 \\
\hline & NCE/ND & 10 & 6.7 \\
\hline & HND/BSC & 67 & 44.7 \\
\hline & M. Sc. & 32 & 21.3 \\
\hline & Ph.D. & 23 & 15.3 \\
\hline & No Response & 12 & 8.0 \\
\hline & Total & 150 & 100.0 \\
\hline \multirow[t]{8}{*}{ Income Level Per Annum (N) } & BELOW 100000 & 29 & 19.3 \\
\hline & $100000-500000$ & 52 & 34.7 \\
\hline & $500000-1000000$ & 18 & 12.0 \\
\hline & $1000000-1500000$ & 12 & 8.0 \\
\hline & $1500000-20000000$ & 19 & 12.7 \\
\hline & 2000,000 and above & 3 & 2.0 \\
\hline & No Response & 17 & 11.3 \\
\hline & Total & 150 & 100.0 \\
\hline
\end{tabular}

The demographic variables of the parents sampled cut across sex, marital status, type of family, education qualifications, and income per annum. From Table 2 above, it was found that the majority of the respondents are females (66.7\%), they fell into the age range of 31 and above and are married (85.3\%). Majority of them work with the government (66\%) and most of the respondents have 2-3 children (45.3\%). This clearly shows that women are usually faced with complexity of decision making when it comes to the issue of child care and that most women that constitute the sampling size in Ado Ekiti city work with the government and have a considerable number of children to cater for.

\section{Empirical Analysis and Findings}

The validation information for this study yielded Cronbach result as presented in Table III below. Validation is internal consistency reliability measure via Statistical Packages for Social Sciences.

Table III: Result of cronbach's alpha testing the reliability of the instrument items

\begin{tabular}{|l|l|c|c|}
\hline \multicolumn{1}{|c|}{ Instrument subscale } & \multicolumn{1}{|c|}{ Measure } & No of Items & Cronbach's Alpha \\
\hline C1-c4 & Parents of either of the spouse & 4 & .638 \\
\hline C5-c8 & Relatives & 4 & .652 \\
\hline C9-c12 & Nanny and Baby sitters & 4 & .786 \\
\hline C13-c16 & Family friends & 4 & .590 \\
\hline C17-c20 & Crèche / Day care centres & 4 & .508 \\
\hline
\end{tabular}


From Table III above, all instrument items ranging from C1- C20 yielded a Cronbach's $\infty$ ranging from 0.5 to 0.78 . The study has threshold objectives; first, it examined the different kinds and combinations of child care arrangements used by parents in Ado Ekiti City. Second, it investigated the parents' perceptions of the different types of child care arrangements. Third, it examined if there is any significant relationship between the demographic features of parents and their perception of each of the child care arrangement identified.

To achieve the first objective, descriptive analysis of the items in Section B (items 1-6, see Appendix) using percentages, frequency counts and mean rating as presented in Table IV and $\mathrm{V}$ below.

Table IV: Different Types of Child Care Arrangement

\begin{tabular}{|l|c|c|c|c|c|c|c|c|c|}
\hline \multirow{2}{*}{ Child Care Arrangements } & \multicolumn{2}{|c|}{ Use } & \multicolumn{2}{c|}{ Not use } & \multicolumn{2}{c|}{ No response } & Mean & S.D & Rank \\
\cline { 2 - 12 } & f & $\%$ & f & $\%$ & f & $\%$ & & & \\
\hline Parents of either of the spouse & 35 & 23.3 & 115 & 76.7 & - & - & 1.2333 & .42437 & 3 \\
\hline Taking Child along to Workplace & 22 & 14.7 & 125 & 83.3 & 3 & 2.0 & 1.1267 & .38940 & 4 \\
\hline Relatives & 19 & 12.7 & 131 & 87.3 & - & - & 1.1267 & .33371 & 4 \\
\hline Nanny and Baby sitters & 56 & 37.7 & 94 & 62.7 & - & - & 1.3733 & .48531 & 2 \\
\hline Family friends & 16 & 10.7 & 130 & 86.7 & 4 & 2.7 & 1.0800 & .35747 & 6 \\
\hline Crèche / Day care centres & 115 & 76.7 & 35 & 23.3 & - & - & 1.767 & .42437 & 1 \\
\hline
\end{tabular}

Table IV above shows different types of child care arrangement that parents do adopt in taking care of their children and it can be observed from the above table that Crèche/Day care centres have the highest level of usage among different categories of parents sampled. It can also be seen that the majority (76.7\%) of the parents indicated the use of this kind of child care arrangement while $23.3 \%$ of the sampled parents indicated that they do not use it. Crèche/Day care centres also had the highest mean value of 1.767 which was ranked first among other kinds of child care arrangement. The child care arrangement that was ranked second was the employment of Nanny and Baby sitters. As it can be seen, $37.7 \%$ of the sampled parents indicated its use and it has the mean value of 1.3733 which was also ranked second. The use of parents of either spouse as a form of child care arrangement was ranked third among other child care arrangement. This kind of child care arrangement has the mean value of 1.233. The practice of taking a child along to one's workplace and the use of relatives as child care agents had the same mean values of 1.1267 each and also had the same rank of 4 th. The kind of child care arrangements which appear to be least used among the sampled parents was the idea of using family friends as child care arrangement option. As it can be noticed in the table, only $10 \%$ of the parents indicated its use with the least mean value of 1.08 and it was ranked $6^{\text {th }}$ among others forms of child care arrangements. This result concludes that the three top most kinds of child care arrangements commonly used by parents were crèche/day care centres; nanny and baby sitters and the use of parents of either spouse as the parents. Furthermore, the study explored the different combination patterns of child care arrangements usually employed by the parents. Table $V$ presents the different combination patterns of child care arrangement while Table VI shows the parents' perception of the different kinds of child care arrangements.

Table V: Different Combination of Parents Child Care Arrangement

\begin{tabular}{|l|c|c|}
\hline \multicolumn{1}{|c|}{ Child care arrangements } & Frequency (f) & Percentage (\%) \\
\hline Parents of either spouse alone & 35 & 16.203 \\
\hline Workplace alone & 22 & 10.185 \\
\hline Nanny and Baby sitter alone & 56 & 25.925 \\
\hline Crèche/Day care centres alone & 115 & 53.240 \\
\hline Relatives alone & 19 & 8.796 \\
\hline Family friends alone & 16 & 7.407 \\
\hline Nanny /Baby sitter and Crèche & 45 & 20.833 \\
\hline Parents and Relatives & 11 & 5.092 \\
\hline Parents, Relatives and Family friends. & 5 & 2.314 \\
\hline \multicolumn{1}{|c|}{ Total } & 324 & 150.00 \\
\hline
\end{tabular}

Table $V$ above shows that $16.2 \%$ of the total sample used parents of the either spouse alone, $10.18 \%$ usually takes their child to their respective workplace, $25.92 \%$ employed the services of nanny and baby sitters, $53.24 \%$ patronized 
crèche/day care centres, $8.7 \%$ and $7.40 \%$ dropped their child with relatives and family friends respectively. The table also show that $20.83 \%$ of the parents sampled used nanny/baby sitters and crèche/day care centres, $5.09 \%$ of parents used parents of the either spouse and relatives whereas, $2.31 \%$ of the parents combined parents of the either spouse, relatives and family friends in their child care arrangements. This shows that some parents sometime combine one or two child care arrangements in order to take good care of their wards while at work.

In examining and analysing the parent's perception of the different kinds of child care arrangements in Ado city, items in section $\mathrm{C}$ of the instrument were scored such that a strongly agree response was given 4 points, agree response was given 3 points, disagree response 2 points while a strongly agree response was given 1 point except for items 17, 19 and 20 that was reversed in scoring. Items 1 through 4 measure perception on the use of parents of either spouse, items 5 through 8 measure perception on the use of relatives, items 9 through 12 measure perception on the use of nanny and baby sitters, items 13 through 16 measure perception on the use of family friends while items 17 through 20 measure perception on the use crèche/day care centres. In order to find out parents perception of each child care arrangement, the respective items in each section were summed up and their mean scores and standard deviations were also obtained. For each section, any respondent with score less than the group mean score was considered as having a negative perception; score from the mean score plus one standard deviation was considered as being indifferent while score with two standard deviation above the mean score was considered as positive perception. The result is therefore presented in Table 5 below:

Table VI: Parents' Perception of the different kinds of Child Care Arrangement

\begin{tabular}{|c|c|c|c|c|}
\hline $\mathrm{S} / \mathrm{N}$ & Family Care Arrangement & Level of perception & $\mathrm{F}$ & $\%$ \\
\hline \multirow{4}{*}{1} & \multirow{4}{*}{ Parents of either Spouse } & Negative & 49 & 32.7 \\
\hline & & Indifferent & 71 & 47.3 \\
\hline & & Positive & 30 & 20.0 \\
\hline & & Total & 150 & 100.0 \\
\hline \multirow{4}{*}{2} & \multirow{4}{*}{ Relatives } & Negative & 49 & 32.7 \\
\hline & & Indifferent & 86 & 57.3 \\
\hline & & Positive & 15 & 10.0 \\
\hline & & Total & 150 & 100.0 \\
\hline \multirow{4}{*}{3} & \multirow{4}{*}{ Nanny and Baby Sitters } & Negative & 91 & 60.7 \\
\hline & & Indifferent & 37 & 24.7 \\
\hline & & Positive & 22 & 14.7 \\
\hline & & Total & 150 & 100.0 \\
\hline \multirow{4}{*}{4} & \multirow{4}{*}{ Family friends } & Negative & 56 & 37.3 \\
\hline & & Indifferent & 82 & 54.7 \\
\hline & & Positive & 12 & 8.0 \\
\hline & & Total & 150 & 100.0 \\
\hline \multirow{3}{*}{5} & \multirow{3}{*}{ Crèche/Day care } & Negative & 30 & 20.0 \\
\hline & & Positive & 120 & 80.0 \\
\hline & & Total & 150 & 100.0 \\
\hline
\end{tabular}

Table 5 above shows that $32.7 \%$ of the parents perceived the use of parents of either spouse as negative, $47.3 \%$ were indifferent while $20.0 \%$ of them perceived it as positive. Similarly, $32.7 \%$ of the parents perceived the use of relatives as child care arrangement as negative, $57.3 \%$ were indifferent while $10.3 \%$ of them perceived it as positive. It is also revealed from the table that the majority of the sampled parents perceived the use of nanny and baby sitters as negative, $24.7 \%$ of the were indifferent while $14.7 \%$ of them perceived it as positive. Also, 37.3 of the parents perceived the use of family friends as negative, $54.7 \%$ were indifferent while only $8.0 \%$ of them perceived it as positive. Finally, the majority of the sampled parents perceived the use of crèche/daycare centres as positive while $20.0 \%$ of them perceived as negative.

\section{Hypothesis Testing:}

There is no significant relationship between the parents' demographic characteristics and their perceptions of each type of child care arrangement?

In order to test this hypothesis, each of the child care arrangements were cross tabulated with such socio- 
demographic variables as sex, educational qualification, type of family and income levels. Their respective chi-square and $p$-values were also obtained. This is presented in Table 6 below:

Table VII: Chi-Square test of significant relationship between the parents' demographic characteristics and their perception of each type of child care arrangements

\begin{tabular}{|c|c|c|c|c|c|c|}
\hline & $\begin{array}{l}\text { Perception of different Family } \\
\text { Care Arrangement }\end{array}$ & $\begin{array}{l}\text { Socio-demographic } \\
\text { Variables }\end{array}$ & $\begin{array}{l}\text { Chi-Square } \\
\text { Values }\end{array}$ & Df & $\begin{array}{c}\mathrm{P}- \\
\text { value }\end{array}$ & Decision \\
\hline & \multirow{4}{*}{ Parents of either Spouse } & Sex & 12.651 & 2 & .002 & Sig \\
\hline \multirow{3}{*}{ 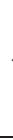 } & & Educational Qualification & 38.360 & 12 & .000 & Sig \\
\hline & & Type of Family & 6.483 & 4 & .166 & Not Sig \\
\hline & & Income Level & 38.634 & 12 & .000 & Sig \\
\hline \multirow{4}{*}{2} & \multirow{4}{*}{ Relatives } & Sex & 3.217 & 2 & .200 & Not Sig \\
\hline & & Educational Qualification & 22.195 & 12 & .035 & Sig \\
\hline & & Type of Family & 36.645 & 4 & .000 & Sig \\
\hline & & Income Level & 24.964 & 12 & .015 & Sig \\
\hline \multirow{4}{*}{3} & \multirow{4}{*}{ Nanny and Baby Sitters } & Sex & 3.898 & 2 & .142 & Not Sig \\
\hline & & Educational Qualification & 33.874 & 12 & .001 & Sig \\
\hline & & Type of Family & 4.803 & 4 & .308 & Not Sig \\
\hline & & Income Level & 28.416 & 12 & .005 & Sig \\
\hline \multirow{4}{*}{4} & \multirow{4}{*}{ Family friends } & Sex & 2.797 & 2 & 247 & Not Sig \\
\hline & & Educational Qualification & 21.561 & 12 & .043 & Sig \\
\hline & & Type of Family & 13.973 & 4 & .007 & Sig \\
\hline & & Income Level & 19.337 & 12 & .081 & Not Sig \\
\hline \multirow{4}{*}{5} & \multirow{4}{*}{ Crèche/Day care. } & Sex & 1.377 & 1 & .241 & Not Sig \\
\hline & & Educational Qualification & 17.798 & 6 & .007 & Sig \\
\hline & & Type of Family & 20.632 & 2 & .000 & Sig \\
\hline & & Income Level & 13.250 & 6 & .039 & Sig \\
\hline
\end{tabular}

Table VII above shows that there is a significant relationship between parents perception of the use of the parents of either spouse as form of child care arrangement on the basis of $\operatorname{sex}\left(X^{2}=12.651, d f=2 ; p=.002\right)$. Also, a significant relationship was found between parents perception of the use of the parents of either spouse as form of child care arrangement and their educational qualification $\left(x^{2}=38.360, d f=12 ; p=.000\right)$. There is also a significant relationship between parents perception of the use of the parents of either spouse as form of child care arrangement on the basis of their income level $\left(\mathrm{X}^{2}=38.634, \mathrm{df}=12 ; \mathrm{p}=.000\right)$. However, the type of family in which parents come has no significant relationship on their perception of the use of the parents of either spouse as a form of child care arrangement. $\left(X^{2}=6.483\right.$, $\mathrm{df}=6.483 ; \mathrm{p}=.166)$.

The table also revealed that sex of the parents has no significant relationship with their perception of the use of relatives as a form of child care arrangement $\left(x^{2}=3.217, d f=2 ; p=.200\right)$ but educational qualification, type of family and income level were found to be significant with parents perception of the use of relatives as a form of child care arrangement. For educational qualification $\left(x^{2}=22.195, d f=12 ; p=. .035\right)$; type of family $\left(X^{2}=36.645, d f=4 ; p=.000\right)$; and Income Level ( $\left.X^{2}=24.964, d f=12 ; p=.015\right)$.

Educational qualification of the parents and their income level were found to be significant with parents' perception of the use of nanny and baby sitters as child care arrangement whereas, sex and type of family of the parent were found not to be significant. Educational qualification $\left(X^{2}=33.874, d f=12 ; p=.001\right)$; income level $\left(X^{2}=28.416, d f=12 ; p=.005\right)$; $\operatorname{sex}\left(X^{2}=3.898, d f=2 ; p=.142\right)$; Type of Family $\left(X^{2}=4.803, d f=4 ; p=.308\right)$.

As regards parents' perception of the use of family friends as child care arrangement, educational qualification and the type of family were found to be significant while sex of the parents and their income level were not significant. Educational Qualification $\left(X^{2}=21.561, d f=12 ; p=.043\right) ; \operatorname{Type}$ of Family $\left(X^{2}=13.973, d f=4 ; p=.007\right) ; \operatorname{Sex}\left(X^{2}=2.797, d f=2\right.$; $p=.247)$ and Income Level $\left(X^{2}=19.337, d f=12 ; p=.081\right)$.

Educational qualifications, type of family and income level of the parents were found to be significant with their perception of the use of crèche/day care centres as child care arrangement while sex was not significant. Educational qualification $\left(X^{2}=17.798, d f=6 ; p=.007\right)$; Type of Family $\left(X^{2}=20.632, d f=2 ; p=.000\right) ; \operatorname{Income}$ Level $\left(X^{2}=13.250, d f=6 ; p=.039\right)$ and $\operatorname{Sex}\left(X^{2}=1.377, d f=1 ; p=.241\right)$. 


\section{Summary of the Findings}

The analysis of the study has revealed important outcomes. First, the study has revealed that working parents in Ado Ekiti city have identified the different child care arrangement options available to them but the study further revealed that the three top most kinds of child care arrangements commonly used by parents were crèche/day care centres; nanny and baby sitters and the use of parents of either spouse. It also revealed that parents combine different kinds of child care arrangements sometimes in order to care for their children while they are at work. It was further found that the parents' demographic variables i.e sex, educational qualifications, type of family and income level have different level of significance with their perceptions of each type of child care arrangement.

Finally, the majority of the sampled parents perceived the use of crèche/daycare centres as positive while $20.0 \%$ of them perceived the use as negative. This implies that the use of early childhood education centres has been embraced by working parents in Ado Ekiti city. Hence it can be concluded that based on the results of this study, child care arrangement that focuses on the development of a total child has been perceived positive by the working parents.

\section{Implication for National Policy on Early Childhood Development Education in Nigeria.}

Child learning programmes in Nigeria have expanded its services to offer pre-school services. Parents often see their wards attendance of pre-school classes as a prestige. Significant aspect of child care has fallen under the purview of State government under the UBE Act 2004 but private efforts are also encouraged in the provision of preprimary education in Nigeria. For example, the Nigeria Policy on Education (2004 edition) made a case for Early Childhood Education as an avenue to allow working mothers concentrate on the work and for easy transition from home to school. The implementation of Universal Basic Education (UBE) programme in 2004 brought to limelight the public participation in the care and education of children in the country.

The state arm of the programme with acronym '(SUBEB)' State Universal Basic Education Board has been saddled with the responsibility of establishing and supervising public pre-primary sections in all public primary schools in the state and there has been a rise in the demand and enrolment of pupils in the kindergarten, crèches and primary schools following the implementation of Universal Basic Education in 2004. Although pre-primary education began as a private sector enterprise in Nigeria, government's participation and ownership particularly at state and local government levels is expanding, courtesy of the UBE Act (2004) which makes pre-primary school an integral part of the UBE Programme. States that are implementing the UBE Programme are expected to integrate pre-primary schools into their public schools. To ensure that the UBE project enjoys a wide coverage, the UBE Act provides sanctions for parents who fail to send their children and wards to school. Also in order to ensure that poverty is not a hindrance to schooling, the project provides free textbooks in core subjects as well as abolishes tuition at the primary school and at the junior secondary school levels. Schools are non-fee paying and are supported with materials and facilities, thereby making preschools affordable and open to more children from financially disadvantaged homes.

Moreover, Ekiti State which was the study area has embraced the UBE programme in its entirety. The state with the slogan "fountain of knowledge" is known to produce the most educated individuals in the country as they place high premium on education and work. Having a job to do is a cultural norm with the belief that "hard work is the antidote of poverty". Most of their citizenry are engaged in the civil service, private establishment, artisans, corporate organizations and self employed. It is thus perceived that while parents are away at work, majority of preschool children in Ado Ekiti regardless of age or income of parents are regularly cared for by individuals other than their parents.

\section{Conclusion and Recommendation}

The study has illuminated our understanding on two key issues namely; the body of knowledge on the concept of child care among working parents within the context of a city in a developing nation. It will also help stakeholders in early childhood education to know the perceptions of working parents on the use of different kinds of child care arrangements in such an environment. The significance of the study to major stakeholders in the field of early childhood education is further reinforced with how the study has carried along the parents' decision making on the use of child care arrangement that will cater for their children total needs. The findings from this study are assumed to help parents make informed decision about an appropriate child care arrangement.

Drawing from National Policy on Education implications on this study, the authors therefore suggest the following recommendations for implementation as a strategy to help encourage the participation of parents especially women in 
the childcare:

- There should be an establishment of crèche or day care centre in all public institutions in order to encourage parents to participate fully in labour force

- There should be public awareness programme for parents on the importance of an appropriate child care arrangement for their wards

- The issue of affordability of privately-owned early childhood centres should be looked into through a standardization of the fee.

- Quality of the existing early childhood education centres in public schools should be raised so that it will act as welfare subsidy for working parents in public institutions.

\section{References}

Anderson, K.A., Foster, J. \& Frisvold, D. (2004). Investing in health: the long term impact of Head Start. Vanderbilt University.

Anderson, P.M. \& Levine, P.B. (1999). Child care and mothers' employment decisions. NBER Working Paper No. W7058, National Bureau of Economic Research, Cambridge, MA.

Capizzano, J., \& Adams, G. (2004). Children in low-income families are less likely to be in center-based child care. Snapshots of America's Families III, 16. Washighton, D.C.: Urban Institute

Casper, L., \& Smith, K. (2004). Self-care: Why do parents leave their children unsupervised? Demography, 41, 285-301.

Huston, A. C., Chang, Y. E., \& Gennetian, L. (2002). Family and individual predictors of child care use by low-income income families in different policy contexts. Early Childhood Research Quarterly, 17(4): 441-469.

Hand, K. (2005). Mothers' views on using formal child care. Family Matters, No. 70, 10-17.

Hofferth, S. L., \& Wissoker, D.A. (1992). Price, quality, and income in child care choice. The Journal of Human Resources, 27(1), 70-111

Meyer, M.K., \& Jordan, L.P. (2006). Choice and Accomodation in Parental Child Care Decisions. Journal of the Community Development Society, 37(2): 65

Federal Republic of Nigeria (2004). National Policy on Education. 